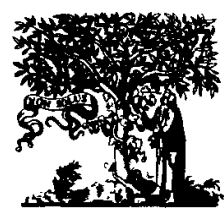

ELSEVIER

\title{
Soil organic matter formation and sequestration across a forested floodplain chronosequence
}

\author{
John D. Wigginton ${ }^{\mathrm{a}, *}$, B. Graeme Lockaby ${ }^{\mathrm{a}}$, Carl C. Trettin ${ }^{\mathrm{b}}$ \\ "School of Forestry, Auburn University', Auburn, AL 36849-5418, USA \\ ${ }^{b}$ USDA Forest Sertice, Center for Forested Wetlands Research, Charleston, SC 29414, USA
}

Received 19 March 1999; received in revised form 18 June 1999; accepted 15 September 1999

\begin{abstract}
Successional changes in soil organic matter formation and carbon sequestration across a forested floodplain chronosequence were studied at the Savannah river site, National Environmental Research Park, SC, US. Four floodplain sites were selected for study, three of which are in various stages of recovery from impact due to thermal effluent discharge. The fourth is a minimally disturbed reference site. Forest floor organic matter increases rapidly during early secondary succession, with a maximum of $657 \mathrm{~g} / \mathrm{m}^{2}$ and decreasing to $338 \mathrm{~g} / \mathrm{m}^{2}$ during the later seral stages. Carbon content in the forest floor also reflected this pattern, with levels greatest during early succession and declining thereafter. Changes in carbon pools of the forest floor are primarily driven by changing levels of forest floor biomass in the various stages of succession, rather than element concentrations. The composition of the forest floor from the various stages differed markedly. The percent herbaceous material declined during succession from $74 \%$ in an early stage to $<1 \%$ in the latest seral stage. Conversely, the amount of woody foliage increased from 6.7 to more than $70 \%$ in late succession. Measures of the degree of transformation of forest floor litter to soil organic matter using the lignocellulose index ( $\mathrm{LCl}$ ) did not differ between stages of succession. Percent lignin and percent cellulose of the forest floor were similar between stages and ranged from 13.8-16.3, and 30.4-32.5\%, respectively. Carbon content of the mineral soil increased with successional stage of the floodplain chronosequence. Soil carbon content ranged from $15.6 \mathrm{~kg} / \mathrm{m}^{2}$ per $0.7 \mathrm{~m}$ in the earliest stage of succession to $55.9 \mathrm{~kg} \mathrm{~m}^{2}$ in late succession. Regression analyses indicated that it may take over 50 years for carbon levels to reach $75 \%$ of that of the reference site. The evidence also suggests that soil structure was disrupted by the disturbance, producing a greater proportion of microaggregates in early seral stages. The formation of soil macroaggregate structure. which may facilitate the accrual of carbon, appears to be occurring slowly. (C) 2000 Elsevier Science B.V. All rights reserved.
\end{abstract}

Kevwords: Soil organic matter; Carbon: Forest floor; Fractionation; Floodplain; Restoration; Succession

* Corresponding author. Tel:: + 1-334-8441056; fax: + 1334-8441084.

E-mail address: wigg@forestry.auburn.edu (J.D. Wigginton).

\section{Introduction}

Restoration is a common practice for mitigating wetland losses in the US (Mitsch and Cronk, 1992; Beck, 1994; Williams and Mice, 1994). This

0925-8574/00/\$ - see front matter 02000 Elsevier Science B.V. All rights reserved.

PII: S0925-8574(99)00080-4 
study is part of a major research project addressing floodplain restoration and assessment criteria. The study is located on Pen branch, a third order stream whose watershed lies entirely within the Savannah river site (SRS) National Environmental Research Park, a US Department of Energy nuclear materials facility adjacent to the Savannah river in South Carolina. Research on Pen branch began when mitigation was required to restore a forested wetland following damages resulting from discharges of thermal effluent into the stream. The final environmental impact statement directed that the area be restored to a functional forested wetland status to the greatest extent possible. One of the primary monitoring and research objectives is to demonstrate the degree to which the Pen branch system is on the theoretical, successional trajectory of a recovering forested wetland (Kentula et al., 1992). Understanding and managing the restoration and recovery process in disturbed wetlands requires an understanding of the successional processes that govern these systems. Therefore, it is the objective of the present study to explore the relationship of soil organic matter development within the context of ecosystem development.

Successional patterns of organic matter dynamics have been well studied in upland systems (Odum, 1960; Switzer et al., 1979; Covington, 1981; Van Cleve and Viereck, 1981), pioneered by E.P. Odum's work in old field succession at the SRS beginning in 1952 . However, there have been few studies on forest floor development and SOM formation during succession in floodplain systems, although Clements (1916) identified floodplains as one of many active physiographic areas where the evidence for succession was most obvious. The hydrologic influences present in floodplain ecosystems likely will alter processes described for upland systems and consequently, the resulting temporal patterns (Lockaby et al., 1996). In addition, successional theory has concentrated primarily on the vegetative community and occasionally on animal communities. Pritchett and Fisher (1987) note that the soil undergoes successive changes as great or greater than that of the plant community, yet because these changes are not as easily observed, they remain unnoticed and unstudied. They suggest that incorporating soil dynamics into our consideration of successional theory could help to understand this complicated phenomenon better and may provide new direction to the perplexing debate on succession.

Although soil organic matter (SOM) constitutes only a small portion of the soil matrix, it contributes to the general chemical and physical properties of the soil and is an essential interface for the exchange of nutrients and energy flow between vegetation and soil (Swift et al., 1979; McColl and Gressel, 1995). Through these effects on soil properties, SOM has a profound influence on forest ecosystem sustainability (Henderson, 1995; McColl and Gressel, 1995). Therefore, given the importance of SOM to forest productivity in general, as well as the biogeochemical linkage provided between aquatic and terrestrial systems by floodplains, it is critical that the process of SOM formation in forested floodplains be understood (Walbridge and Lockaby, 1994; Henderson, 1995). Consequently, we are studying forest floor development and SOM formation in four seral stages of a floodplain forest at SRS. Our general objective is to ascertain how the: (1) characteristics of the organic horizon; (2) rates of conversion of plant litter to SOM; and (3) accrual of SOM within biologically significant fractions of the mineral soil, change during the successional trajectory of a floodplain forest.

\subsection{Hypotheses}

We believe that forest floor mass and carbon (C) will reach a maximum during middle succession, declining as succession proceeds thereafter (Switzer et al., 1979). The pulse of vegetation productivity by colonizing species during early succession should result in increasing additions to the forest floor. As succession proceeds, equilibrium is reached between respiration and productivity, contributing to a loss of excess C (Switzer et al., 1979).

In addition, we hypothesize that the level of transformation of litter to SOM (as measured by the lignocellulose index, LCI) will be greatest during early stages of succession and reach equilibrium during middle stages of succession. The 
LCI represents an estimate of the stage of transformation of plant litter to the SOM pool, using the ratio of lignin to lignin + cellulose (Melillo et al., 1989). Higher ratios are predicted in later stages of succession due to the expected increase in a refractory lignin component over time. The LCI ratio increases rapidly with mass loss during an initial phase of decomposition. As the LCI ratio approaches 0.7 , decomposition enters a second phase that is more stable, being controlled by recalcitrant materials such as lignin (Melillo et al., 1989; Lockaby et al., 1996).

Thirdly, the redevelopment of macroaggregate structure during succession will be accompanied by a concomitant increase in soil organic $\mathrm{C}$ (Jastrow, 1996). The loss of SOM in certain soil fractions with long-term cultivation has been well studied. For example, macroaggregate-associated organic matter has been shown to decline with the level of cultivation (Elliott, 1986; Cambardella and Elliott, 1992, 1993a, 1994; Jastrow, 1996). Similar soil degradation is expected at SRS where these soil systems were subjected to severe disturbance for about 35 years (Dulohery et al., 1995).

Organic matter in soils may be physically or chemically stabilized (or 'protected') against decomposition. Physically stabilized SOM is related to soil structure (Killham, 1994) and some of this stabilized organic matter may be exposed to decomposition when management practices disrupt aggregate structure. Traditionally, fractions of SOM have been examined primarily through the use of chemical fractionation procedures (Christensen, 1992; Cambardella and Elliott, 1993b), and are used to classify humic substances into humic acids, fulvic acids, or humins (Theng and Tate, 1989; Stevenson, 1994). Physical fractionation, however, is considered to be a less destructive, more selective method of attaining biologically significant fractions of soil aggregates that are more representative of the structure and function of SOM in a natural system (Christensen, 1992). Conversely, chemical fractionation may expose organic matter that is physically protected and not readily available for decomposition by microorganisms (Elliott and Cambardella, 1991; Cambardella and Elliott, 1994). Therefore, fractions obtained by physical procedures may be more useful in describing the dynamic processes in soils (Oades, 1989), as soil fractions of different particle sizes are assumed to have different roles in SOM function and turnover (Christensen, 1992). Additionally, it has been found that any soil fraction, regardless of the proportion to the overall soil, may have a very important role in overall soil functioning (Kanazawa and Filip, 1986; Ellert and Gregorich, 1995).

Since there is a paucity of information available concerning SOM fractions of wetlands, or any Southeastern system, the results of this study will begin to fill a major void in the literature concerning SOM dynamics of wetlands in general, and specifically southeastern floodplain forests. Knowledge of the quantity and quality of SOM in soil fractions at Pen branch may provide a better understanding of the accumulation of the entire pool of soil $\mathrm{C}$ and the formation of aggregate structure. This knowledge then may be helpful in assessing the state of overall ecosystem restoration at Pen branch.

\section{Methods}

\subsection{Disturbance history and description of study site}

The study sites are located on the floodplains of Pen branch (upper corridor), Fourmile creek, and Meyers branch of the Savannah river site, $\mathrm{Na}$ tional Environmental Research Park. Streams of the SRS are typical of blackwater streams of the Southeastern Coastal Plain. Stream channels are characterized by a shifting sand substratum and have a $100-200 \mathrm{~m}$ wide floodplain. In a minimally disturbed situation such as Meyers branch, the floodplain is well developed with wetland vegetation, creating an enclosed stream corridor (Hauer, 1989). Soil at the Pen branch and Fourmile creek study sites is a siliceous, thermic Typic Psammaquent (Totness series; D. DeFrancesco, pers. commun.), and Meyers branch soil is a sandy, siliceous, thermic, Cumulic Humaquept (Pickney series; Rogers, 1990). Therefore, taxonomic classification suggests that Meyers branch is an excellent reference site. It differs only in being slightly 
more developed and having greater humus accumulation, characteristics which are expected and desired for comparison with the more recently disturbed sites.

Pen branch and Fourmile creek are third order tributaries of the Savannah river that received thermal effluent from nuclear reactors on the SRS from 1954 to 1989 , and 1955 to 1985. respectively. During this period the base flow rate at Pen branch increased more than 30-fold from about 0.3 to $11 \mathrm{~m}^{3} / \mathrm{s}$ and average annual temperature of the reactor effluent was as great as $70^{\circ} \mathrm{C}$. Consequently, the floodplains of both tributaries were virtually denuded of vegetation due to scalding of plants to the roots and increased erosion from greater flow rates (Dulohery et al., 1995).

Reforestation efforts of the Pen branch upper corridor occurred from September 1993 to January 1995. The area was divided into six strips perpendicular to the stream channel, with three treatment strips comprising $75 \%$ of the upper corridor and the remainder of the area in three unplanted, control strips (see Fig. 1, Kolka et al., this issue). Site preparation techniques included the application of herbicide (Rodeo) to control willows in September 1993 and burning in November 1993 to improve access for tree planting. In December 1993 and January 1994. trees were planted to achieve a target density of about 750 trees per hectare in the upper corridor. Extensive mortality, due primarily to feral hog herbivory, left only about 230 trees per

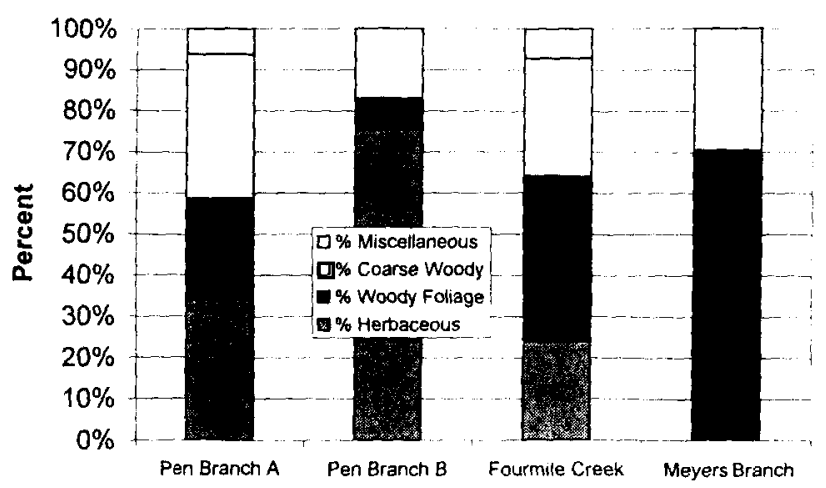

Fig. 1. Percent coarse woody, woody foliage, and herbaceous material in forest floor samples of four successional stages of a floodplain at the Savannah river site. hectare. To compensate for this mortality, an additional 1100 trees per hectare were planted in January 1995. Untreated strips also were maintained in which there was no herbicide application or tree planting (Dulohery et al., 1995). Accordingly, a study site was' established at the uppermost control strip, which will be referred to as 'Pen branch $A$ ', as well as the adjacent treatment strip, 'Pen branch B'.

The dominant tree species of the treatment area of Pen branch are primarily red maple (Acer rubrum) and black willow (Salix nigra), with dense undergrowth of blackberry (Rubus spp.). The control area of Pen branch is similar in vegetation, but also includes significant numbers of wax myrtle (Myrica cerifera). Fourmile creek is dominated by black willow, wax myrtle, and alder (Alnus serrulata), with less shrub material (Rubus spp.) than the Pen branch floodplain.

At the time of sampling, April and June of 1996, the Pen branch floodplain had been in successional recovery for 7 years, and due to the site treatments and reforestation efforts at Pen branch $B$, it is considered to be in a more advanced state of succession than Pen branch $\mathrm{A}$. Fourmile creek is 11 years post-disturbance, and represents a more mature stage of development that is transitional from a shrub-dominated Pen branch system to a forested system. Thus, in our regression analyses, we assigned a value of 9 years to Pen branch $B$, a value falling between Pen branch $A$ and Fourmile creek. Meyers branch, an unimpacted tributary supporting an old growth bottomland-hardwood ecosystem of cypress (Taxodium distichum), red maple, and swamp tupelo (Nyssa sylvatica var. biflora) represents a more mature stage of successional development. The land surrounding Meyers branch was abandoned in the 1930s and 1940s from agriculture and had extensive selective logging. The oldest vegetation is approximately 75 years old, although relic cypress exist that are estimated to be $>600$ years (W.H. Conner, pers. commun.). For regression analyses, we used the value of 75 years for Meyers branch. 


\subsection{Sampling methodology.}

\subsubsection{Experimental design}

The experimental design is based on a chronosequence concept in which it is assumed that all major environmental factors such as geology, precipitation, temperature, sunlight, disturbance intensity, etc., are similar among the floodplains. This assumption should be satisfied, as the four sites are within $15 \mathrm{~km}$ of each other and are part of the Savannah river floodplain. The treatment is the recovery period since hydrothermal impact, with Meyers branch representing a reference site. Therefore, differences in forest floor and soil properties among the floodplains are attributed primarily to successional change (time since disturbance), and it is assumed that the Pen branch and Fourmile creek floodplains are on a successional trajectory similar to that of the Meyers branch ecosystem.

Soil variables were first analyzed for significant variation with distance from the stream channel by visually inspecting scatter plots of the data and by analysis of variance. There were no significant relationships found among any of the soil variables and distance. Therefore, samples were pooled with respect to distance from the stream channel and differences among sites were analyzed by ANOVA and regression analysis at the 0.05 probability level.

\subsubsection{Forest floor}

At each of the four seral stages (Pen branch A, Pen branch B, Fourmile creek, Meyers branch) a transect was randomly delineated across the floodplain, perpendicular to the stream. Forest floor samples were collected at $10-\mathrm{m}$ intervals along the transect using a $0.1 \mathrm{~m}^{2}$ sampling square. Samples were transferred to the laboratory, ovendried at $70^{\circ} \mathrm{C}$ for $72 \mathrm{~h}$, and separated into fractions of woody debris (stems and branches of tree origin), tree foliage, and herbaceous/shrubby vegetation. Samples were weighed and ground to pass a 20-mesh sieve and a subsample was analyzed for total $\mathrm{C}$ concentration by dry combustion with a Perkin-Elmer 2400 Series II CHNS/O analyzer (Perkin-Elmer Corp., Norwalk. CT). Using the methodology of Van Soest and Wine (1968), lignin and cellulose estimates were obtained from composite samples of the fractions from each plot.

\subsubsection{Soil}

Soil samples were collected at the same plots that forest floor samples were taken, using a $7 \mathrm{~cm}$ diameter steel coring bit to remove one $7.5 \mathrm{~cm}$ core at 0,30 , and $60 \mathrm{~cm}$ depths. The methodology used for analyzing the soil samples follows that of Cambardella and Elliott (1994). After air drying, samples were passed through a $2.8-\mathrm{mm}$ sieve to remove rock and larger organic matter fragments. Debris greater than about 2-mm that passed through the sieve was removed by hand. A subsample (usually about $200 \mathrm{~g}$, depending on original sample size and soil texture) from each plot depth was pre-wetted overnight to field capacity and separated by wet-sieving into ? Jur size classes of $>2000 \mu \mathrm{m}$ (macroaggregates), $250-2000 \mu \mathrm{m}$ (small macroaggregates), 53-250 $\mu \mathrm{m}$ (microaggregates), and $<53 \mu \mathrm{m}$ (silt-clay size particles). Samples were dried overnight in a $65^{\circ} \mathrm{C}$ oven. Subsamples of the initial size fractions were analyzed for total $\mathrm{C}$ by dry combustion as described above. The micro- and macroaggregates were subjected to more intensive fractionation, in which samples were separated into 12 and 15 fractions. respectively, based on both size and density characteristics (Cambardella and Elliott, 1994). Data on these size-density fractions will be presented in a future paper.

The contribution of each soil fraction to total C in the whole soil was determined by multiplying the element concentration for a given fraction by the amount of soil in that fraction. Soil amounts at the 0 and $30 \mathrm{~cm}$ depths were calculated using our bulk density estimates ( $n=48$ and 14 , respectively). Bulk density values of $0.84,0.90$, and 0.32 $\mathrm{mg} / \mathrm{m}^{3}$ were calculated for the surface depth at Pen branch, Fourmile creek and Meyers branch, respectively. At $30-\mathrm{cm}$ depth, $1.1 \mathrm{mg} / \mathrm{m}^{3}$ was used at Pen branch and Fourmile creek sites, while 0.64 was estimated at Meyers branch. Bulk density for the $60-\mathrm{cm}$ depth was estimated using USDANRCS soil survey data and supported by limited data from this study. The Totness series soil of Pen branch and Fourmile creek is newly de- 
Table 1

Comparison of forest floor characteristics in a chronosequence of floodplain forests at the Savannah river site ${ }^{a}$

\begin{tabular}{llllll}
\hline Site & Total mass $\left(\mathrm{g} / \mathrm{m}^{2}\right)$ & Total $\mathrm{C}\left(\mathrm{g} \mathrm{m} \mathrm{m}^{2}\right)$ & Lignin $(\%)$ & Cellulose $(\%)$ & LCI \\
\hline Pen branch A & $656.7 \mathrm{a}(134.9)^{\mathrm{b}}$ & $293.3 \mathrm{a}(60.4)$ & $16.26 \mathrm{a}(0.71)$ & $31.86 \mathrm{a}(0.58)$ & $0.338 \mathrm{a}(0.014)$ \\
Pen branch B & $432.6 \mathrm{ab}(64.1)$ & $164.6 \mathrm{~b}(26.2)$ & $13.73 \mathrm{a}(0.81)$ & $30.37 \mathrm{a}(1.56)$ & $0.315 \mathrm{a}(0.023)$ \\
Fourmile creek & $444.7 \mathrm{ab}(94.4)$ & $184.5 \mathrm{ab}(40.7)$ & $14.51 \mathrm{a}(1.30)$ & $32.55 \mathrm{a}(1.45)$ & $0.308 \mathrm{a}(0.026)$ \\
Meyers branch & $337.8 \mathrm{~b}(65.2)$ & $139.0 \mathrm{~b}(30.6)$ & $15.08 \mathrm{a}(0.69)$ & $31.72 \mathrm{a}(1.24)$ & $0.324 \mathrm{a}(0.019)$ \\
\hline
\end{tabular}

a Pen branch A and B are 7 years post hydro-thermal disturbance, with Pen branch B having received restoration efforts. Fourmile creek is 11 years post-disturbance, and Meyers branch is a $\sim 75$-year-old minimally disturbed, reference site (see text).

${ }^{b}$ Mean dry weight with S.E. of the mean in parentheses; $N=9$ for PBA, $N=11$ for PBB, $N=7$ for $4 \mathrm{M}$, and $N=8$ for $\mathrm{MB}$; means in a column followed by the same letter are not significantly different at $P>0.05$, according to Duncan's multiple range test.

scribed, and complete information on this series was provided by Dennis DeFrancesco (soil scientist, NRCS, Greenville, SC). The soil survey for the Savannah river plant (Rogers, 1990) lists these soils as Fluvaquents, and the bulk density values given are nearly identical to that for the Totness series. Bulk density for the Totness series at $60-\mathrm{cm}$ is 1.5 , and $1.3 \mathrm{mg} / \mathrm{m}^{3}$ for the Pickney series (Meyers branch).

\section{Results}

\subsection{Forest floor}

Forest floor organic matter increases rapidly during early succession, with a maximum of 657 $\mathrm{g} / \mathrm{m}^{2}$ observed at Pen branch $\mathrm{A}$, and steadily decreasing to $338 \mathrm{~g} / \mathrm{m}^{2}$ during late seral stages (Table 1). Carbon content also reflected this pattern, with $293 \mathrm{~g} / \mathrm{m}^{2}$ at Pen branch A and $139 \mathrm{~g} / \mathrm{m}^{2}$ at Meyers branch (Table 1).

Comparison of forest floor composition revealed that herbaceous species dominate early seral stages and are slowly replaced by woody species during middle and late succession (Fig. 1). The percent herbaceous material was 34 at Pen branch $\mathrm{A}$ and declined through succession to less than $1 \%$ at Meyers branch. Pen branch B had the greatest percentage herbaceous material at $74 \%$. Conversely, the amount of woody foliage increased during succession from 7 and $24 \%$ at the Pen branch B and A sites, respectively, to more than $70 \%$ at Meyers branch (Fig. 1).
Measures of the level of transformation of litter to soil organic matter using the LCI were not significantly different among stages, ranging between 0.31 and 0.34 (Table 1). Percent lignin and cellulose in forest floor material was similar among stages, ranging from 13.7 to $16.3 \%$, and 30.4-32.6\%, respectively (Table 1). Results of ANOVA tests for forest floor variables are presented in Table 2.

\subsection{Mineral soil}

\subsubsection{Carbon content across depths}

Results of ANOVA tests for all mineral soil variables are presented in Table 3. Carbon content of the soil profile (top $70 \mathrm{~cm}$ ) increases with successional stage of the floodplain chronosequence, from 15.6 to $55.9 \mathrm{~kg} / \mathrm{m}^{2}$ (Table 4). Levels of $\mathrm{C}$ in Pen branch A, Pen branch B and Fourmile creek are significantly lower than the Meyers branch reference site. Although differences in the means for total $\mathrm{C}$ in the three younger stages are not significant, there is a numerical increase with

Table 2

$F$-value, $P$-value, and $R^{2}$ for analysis of variance of forest floor variables across a floodplain chronosequence at the Savannah river site

\begin{tabular}{llll}
\hline Variable & $F$-value & $P$-value & $R^{2}$ \\
\hline Total mass $\left(\mathrm{g} / \mathrm{m}^{2}\right)$ & 2.06 & 0.1258 & 0.17 \\
Total C $\left(\mathrm{g} / \mathrm{m}^{2}\right)$ & 2.76 & 0.0588 & 0.21 \\
Lignin $(\% / 1)$ & 1.65 & 0.1977 & 0.14 \\
Cellulose $(\%)$ & 0.52 & 0.6710 & 0.04 \\
LCI & 0.35 & 0.7879 & 0.03 \\
\hline
\end{tabular}


Table 3

$F$-value, $P$-value, and $R^{2}$ for analysis of variance of mineral soil variables across a floodplain chronosequence at the Savannah river site

\begin{tabular}{lccc}
\hline Variable & $F$-value & $P$-value & $R^{2}$ \\
\hline Total $\left.(\mathrm{kg} \mathrm{m})^{2}\right)$ & 18.8 & 0.0001 & 0.62 \\
Aggregate distribution & & & \\
$>2000 \mu \mathrm{m}$ & 4.81 & 0.0071 & 0.31 \\
$250-2000 \mu \mathrm{m}$ & 20.7 & 0.0001 & 0.66 \\
$53250 \mu \mathrm{m}$ & 12.6 & 0.0001 & 0.54 \\
$<53 \mu \mathrm{m}$ & 5.51 & 0.0036 & 0.34 \\
Total $\mathrm{C}\left(\mathrm{kg}^{\prime} \mathrm{m}^{2}\right)$ & & & \\
$>2000 \mu \mathrm{m}$ & 11.6 & 0.0028 & 0.81 \\
$250-2000 \mu \mathrm{m}$ & 1.66 & 0.2518 & 0.38 \\
$53-250 \mu \mathrm{m}$ & 1.60 & 0.2638 & 0.38 \\
$<53 \mu \mathrm{m}$ & 6.43 & 0.0159 & 0.71 \\
& & &
\end{tabular}

Table 4

Comparison of total $\mathrm{C}\left(\mathrm{kg} \mathrm{m}^{2}\right.$ to $0.7 \mathrm{~m}$ depth) in a chronosequence of floodplain forests at the Savannah river site

\begin{tabular}{lc}
\hline Site & Total $\mathrm{C}\left(\mathrm{kg} \mathrm{\textrm {m } ^ { 2 } )}\right.$ \\
\hline Pen branch A & $15.56 \mathrm{a}(2.47)^{\mathrm{a}}$ \\
Pen branch B & $19.13 \mathrm{a}(2.74)$ \\
Fourmile creek & $23.28 \mathrm{a}(4.84)$ \\
Meyers branch & $55.87 \mathrm{~b}(6.21)$
\end{tabular}

"S.E. of the mean in parentheses; $N=12$ for PBB and $N=9$ for all other sites: means in a column followed by the same letter are not significantly different at $P>0.05$, according to Duncan's multiple range test.

time (Table 4). The regression model depicted in Fig. 2 best describes the influence of succession on $C$ aggradation in the solum of these floodplain soils. The slope of the regression line is highly significant $(T=7.59, P<0.0001)$.

\subsubsection{Aggregate distribution}

When examined across depths, several differences among sites were found in the percent distribution of soil aggregate size classes. There is a significantly smaller proportion of soil in the macroaggregate $(>2000 \mu \mathrm{m})$ fraction of the three recently disturbed sites. Meyers branch samples have $23.5 \%$ macroaggregates, whereas the recently disturbed, earlier succession floodplain sites only exhibit $10-12 \%$ in this fraction (Table 5). Four- mile creek has a significantly greater proportion (over $62 \%$ ) in the small macroaggregate $(250-$ $2000 \mu \mathrm{m}$ ) fraction than the Pen branch sites and Meyers branch, which are between 26 and $37 \%$ (Table 5). Fourmile creek also is significantly different than the other sites in having a smaller proportion in the silt-clay size $(<53 \mu \mathrm{m})$ fraction (Table 5). Pen branch $\mathrm{A}$ and $\mathrm{B}$ have about twice the proportion in the microaggregate (53$250 \mu \mathrm{m})$ fraction as that of Fourmile creek and Meyers branch (Table 5).

When aggregate distribution is examined by depth, it is found that most of the variation observed among sites is largely attributable to differences at the 0 and $30-\mathrm{cm}$ depths. No significant variation among sites was observed at $60-\mathrm{cm}$ depth (Table 6). At 0-cm depth, the disturbed sites have a smaller percentage in the macroaggregate class and the pattern is similar at $30-\mathrm{cm}$ (Table 6). Macroaggregate percentage at $0-\mathrm{cm}$ depth was less in the Pen branch sites than at Meyers branch, but the percentage at Fourmile creek was greater than Meyers branch (Table 6). At 30-cm depth, the percent of small macroaggregates at Fourmile creek was more than twice the other sites. Microaggregate percentage was significantly greater at Pen branch $\mathrm{A}$ and $\mathrm{B}$ than Fourmile creek and Meyers branch at both 0 and $30-\mathrm{cm}$ depths.

\subsubsection{Carbon content in aggregate size classes}

Carbon content at Meyers branch was greater for each fraction than all other stages, ranging from $6.7 \mathrm{~kg} \mathrm{C} / \mathrm{m}^{2}$ in the silt-clay fraction to 19.8 $\mathrm{kg} \mathrm{C} / \mathrm{m}^{2}$ in small macroaggregates (Table 7). The greatest difference in $\mathrm{C}$ content between Meyers branch and the other sites was in the macroaggregate fraction, in which $\mathrm{C}$ ranged from 3.1 to 5.1 $\mathrm{kg} / \mathrm{m}^{2}$ in earlier succession, but was $10.1 \mathrm{~kg} / \mathrm{m}^{2}$ at Meyers branch (Table 7). This difference in $\mathrm{C}$ content was a function of both a smaller percentage of macroaggregates in the early seral stages, and a lesser element concentration. Regression models depicting the change in $\mathrm{C}$ content of size fractions during succession were similar to that described for whole soil (Fig. 2; Table 8). 




Fig. 2. The relationship between mineral soil $\mathrm{C}$ content and succession in a forested floodplain chronosequence at the Savannah river site.

\section{Discussion}

\subsection{Forest floor}

Our data suggest that forest floor mass increases rapidly after disturbance, as levels were greatest at Pen branch A, 7 years post recovery. Thereafter, mass also declines rapidly, however, as Fourmile creek was not significantly different from Meyers branch, and regression analysis indicates that an equilibrium of about $350 \mathrm{~g} / \mathrm{m}^{2}$ is reached in $\sim 25$ years (Fig. 3). Covington (1981), studying forest floor organic matter responses to clear cutting in northern hardwoods, found that forest floor mass declined for the first 15 years of succession, followed by a 50 -year period of aggra-

Table 5

Comparison of percent aggregate distribution across depth in floodplain soils at the Savannah river site

\begin{tabular}{lllll}
\hline Site & $\begin{array}{l}\text { Silt-clay } \\
(<53 \mu \mathrm{m})\end{array}$ & $\begin{array}{l}\text { Microaggregates } \\
(53-250 \mu \mathrm{m})\end{array}$ & $\begin{array}{l}\text { Small macroaggregates } \\
(250-2000 \mu \mathrm{m})\end{array}$ & $\begin{array}{l}\text { Macroaggregates } \\
(>2000 \mu \mathrm{m})\end{array}$ \\
\hline Pen branch A & $16.33 \mathrm{a}(1.81)^{\mathrm{a}}$ & $44.68 \mathrm{a}(4.77)$ & $28.62 \mathrm{a}(3.76)$ & $10.38 \mathrm{a}(1.88)$ \\
Pen branch B & $12.08 \mathrm{a}(1.50)$ & $49.45 \mathrm{a}(3.53)$ & $26.42 \mathrm{a}(2.77)$ & $12.05 \mathrm{a}(2.02)$ \\
Fourmile creek & $7.30 \mathrm{~b}(1.48)$ & $20.32 \mathrm{~b}(3.37)$ & $62.03 \mathrm{~b}(5.38)$ & $10.35 \mathrm{a}(2.04)$ \\
Meyers branch & $12.49 \mathrm{a}(1.49)$ & $27.27 \mathrm{~b}(3.79)$ & $36.74 \mathrm{a}(0.95)$ & $23.49 \mathrm{~b}(4.65)$
\end{tabular}

"S.E. of the mean in parentheses; means in a column followed by the same letter are not significantly different at $P>0.05$, according to Duncan's multiple range test: $N=9$ for each fraction at each site. 
Table 6

Percent distribution by depth of four particle size fractions in floodplain soils at the Savannah river site

\begin{tabular}{|c|c|c|c|c|c|}
\hline Site & $\begin{array}{l}\text { Depth } \\
(\mathrm{cm})\end{array}$ & $\begin{array}{l}\text { Silt-clity } \\
(<53 \mu \mathrm{m})\end{array}$ & $\begin{array}{l}\text { Microaggregates } \\
(53-250 \mu \mathrm{m})\end{array}$ & $\begin{array}{l}\text { Small macroaggregates } \\
(250) .2000 \mu \mathrm{m})\end{array}$ & $\begin{array}{l}\text { Macroaggregates } \\
(>2000 \mu \mathrm{m})\end{array}$ \\
\hline \multirow{3}{*}{ Pen branch $A$} & 0 & 17.1 & $52.5 \mathrm{a}$ & $19.5 c$ & $11.0 \mathrm{~b}$ \\
\hline & 30 & $20.1 \mathrm{a}$ & $36.6 \mathrm{a}^{\mathrm{b}}$ & $28.6 \mathrm{~b}$ & $14.7 \mathrm{ab}$ \\
\hline & 60 & 11.8 & 45.0 & .37 .8 & 5.5 \\
\hline \multirow[t]{3}{*}{ Pen branch B } & 0 & 12.2 & $49.7 \mathrm{a}$ & $21.6 c$ & $16.5 b$ \\
\hline & 30 & $14.8 \mathrm{a}$ & $49.5 \mathrm{a}$ & $23.5 \mathrm{~b}$ & $12.2 \mathrm{ab}$ \\
\hline & 60 & 9.2 & 49.1 & 34.2 & 7.5 \\
\hline \multirow[t]{3}{*}{ Fourmile creek } & 0 & 8.2 & $18.3 \mathrm{~b}$ & $61.1 \mathrm{a}$ & $12.5 b$ \\
\hline & 30 & $5.0 \mathrm{~b}$ & $16.0 b$ & $74.0 \mathrm{a}$ & $5.1 \mathrm{~b}$ \\
\hline & 60 & 8.7 & 26.7 & 51.0 & 13.5 \\
\hline \multirow{3}{*}{ Meyers branch } & 0 & 10.0 & $16.5 b$ & $34.9 \mathrm{~b}$ & $38.6 \mathrm{a}$ \\
\hline & 30 & $17.1 \mathrm{a}$ & $25.7 b$ & $35.7 b$ & $21.5 \mathrm{a}$ \\
\hline & 60 & 10.3 & 39.7 & 39.6 & 10.4 \\
\hline
\end{tabular}

"Means in a column followed by the same letter are not significantly different at $P>0.05$, according to Duncan's multiple range test, and apply only to means of the same depth in that column; results of Duncan's test shown only when significant differences occur for depth in a column: $N=3$ for each depth in each fraction.

${ }^{\mathrm{b}}$ Value for PBA is significantly different from $4 \mathrm{M}$ and $\mathrm{MB}$ at $P<0.10$.

Table 7

Comparison of total soil $\mathrm{C}\left(\mathrm{kg} \mathrm{m}^{2}\right.$ per $\left.0.7 \mathrm{~m}\right)$ in particle size fractions of foodplain soils at the Savannah river site"

\begin{tabular}{lllll} 
Site & $\begin{array}{l}\text { Silt clay } \\
(<53 \mu \mathrm{m})\end{array}$ & $\begin{array}{l}\text { Microaggregates } \\
(53-250 \mu \mathrm{m})\end{array}$ & $\begin{array}{l}\text { Small macroaggregates } \\
(2502000 \mu \mathrm{m})\end{array}$ & $\begin{array}{l}\text { Macroaggregates } \\
(>2000 \mu \mathrm{m})\end{array}$ \\
\hline Pen branch A & $3.73 \mathrm{a}(0.36)$ & $4.16 \mathrm{a}(1.37)$ & $4.98 \mathrm{a}(0.56)$ & $3.13 \mathrm{a}(0.47)$ \\
Pen branch B & $4.02 \mathrm{a}(0.80)$ & $6.13 \mathrm{a}(1.56)$ & $8.83 \mathrm{a}(3.32)$ & $4.23 \mathrm{a}(1.29)$ \\
Fourmile creek & $3.01 \mathrm{a}(0.42)$ & $4.75 \mathrm{a}(0.34)$ & $14.82 \mathrm{a}(9.13)$ & $5.06 \mathrm{a}(0.97)$ \\
Meyers branch & $6.74 \mathrm{~b}(0.79)$ & $8.98 \mathrm{a}(1.76)$ & $19.79 \mathrm{a}(5.45)$ & $10.12 \mathrm{~b}(2.48)$
\end{tabular}

a S.E. of the mean in parentheses: $N=3$ for each fraction at each site: means in a column followed by the same letter are not significantly different at $P>0.05$, according to Duncan's multiple range test.

Table 8

Regression equations of time on C content in particle size fractions of floodplain soils at the Savannah river site (x. time in vears)

\begin{tabular}{|c|c|c|c|c|}
\hline Fraction & Regression equation & $F$-value & $P$-value & $R^{2}$ \\
\hline Silt clay $(<53 \mu \mathrm{m})$ & $\mathrm{kg} \mathrm{Cm}^{2}=3.172+0.005 x$ & 22.7 & 0.0008 & 0.69 \\
\hline Microaggregates $(53-250 \mu \mathrm{m})$ & $\mathrm{kg} \mathrm{C} \mathrm{m} \mathrm{m}^{2}=4.468+0.060 x$ & 9.43 & 0.0118 & 0.49 \\
\hline Small macroaggregates $\{250-2000 \mu \mathrm{m}\}$ & $\mathrm{kg} \mathrm{Cm}^{2}=22.25-113.2 x$ & 6.06 & 0.0336 & 0.38 \\
\hline Macroaggregates $(>2000 \mu \mathrm{m})$ & $\mathrm{kgC} \mathrm{m}{ }^{2}=3.301+0.091 x$ & 14.1 & 0.0037 & 0.59 \\
\hline
\end{tabular}

dation that stabilized at $5600 \mathrm{~g} / \mathrm{m}^{2}$. Mattson and Smith (1993) also found an initial phase of mass loss for 10 years after cutting, with minimal change occurring thereafter until 23 years. Switzer et al. (1979), in a study of upland forests in eastern Mississippi, reported an aggrading forest floor, with maximum levels of $2100 \mathrm{~g} / \mathrm{m}^{2}$ attained during mid-succession (50-100 years) and declining to $1400 \mathrm{~g} / \mathrm{m}^{2}$ thereafter. An initial period of decline, sensu Covington (1981) and Mattson and Smith (1993), was not described, but sites less than 15 years were not studied. Decreases in 
forest floor mass immediately following harvest are documented (Witkamp, 1971; Marks and Bormann, 1972; Aber et al., 1978; Johnson et al., 1985), and usually are attributed to greater decomposition rates from increases in soil temperature, moisture content, and nutrient availability (Covington, 1981).

Despite the overriding hydrologic influences in floodplains, our analyses suggest that the pattern of development of the forest floor during floodplain succession is similar to that found in forested uplands. However, equilibrium in forest floor mass of southeastern upland forests is reached in about 150 years (Switzer et al., 1979), and 65 years in northern hardwood forests (Covington, 1981); periods much longer than $\sim 25$ years suggested by our results for southeastern floodplain forests. An initial period of decline in forest floor mass would not have occurred in this study, as discussed for uplands, because most of the forest floor material was transported downstream.
Two primary factors may contribute to a more rapid achievement of equilibrium in forest floor mass of southeastern floodplains. First, early successional upland forests in the Southeast are heavily dominated by pine (Pinus spp.), comprising as much as $85 \%$ basal area in stand age up to 40 years (Switzer et al., 1979), whereas patterns of succession in floodplain forests are minimally influenced by pines (Hodges, 1997). Decades of succession in which seral stages are dominated by pine will change the overall forest floor dynamic compared to a sere with little or no pine component. For example, deciduous litter decomposes faster than coniferous litter (Vogt et al., 1986). The lack of pine influence also may explain why equilibrium is reached faster in northern hardwood uplands (Covington, 1981) versus southeastern uplands (Switzer et al., 1979). Second, forested floodplains are usually more productive than upland forests (Sharitz and Mitsch, 1993),

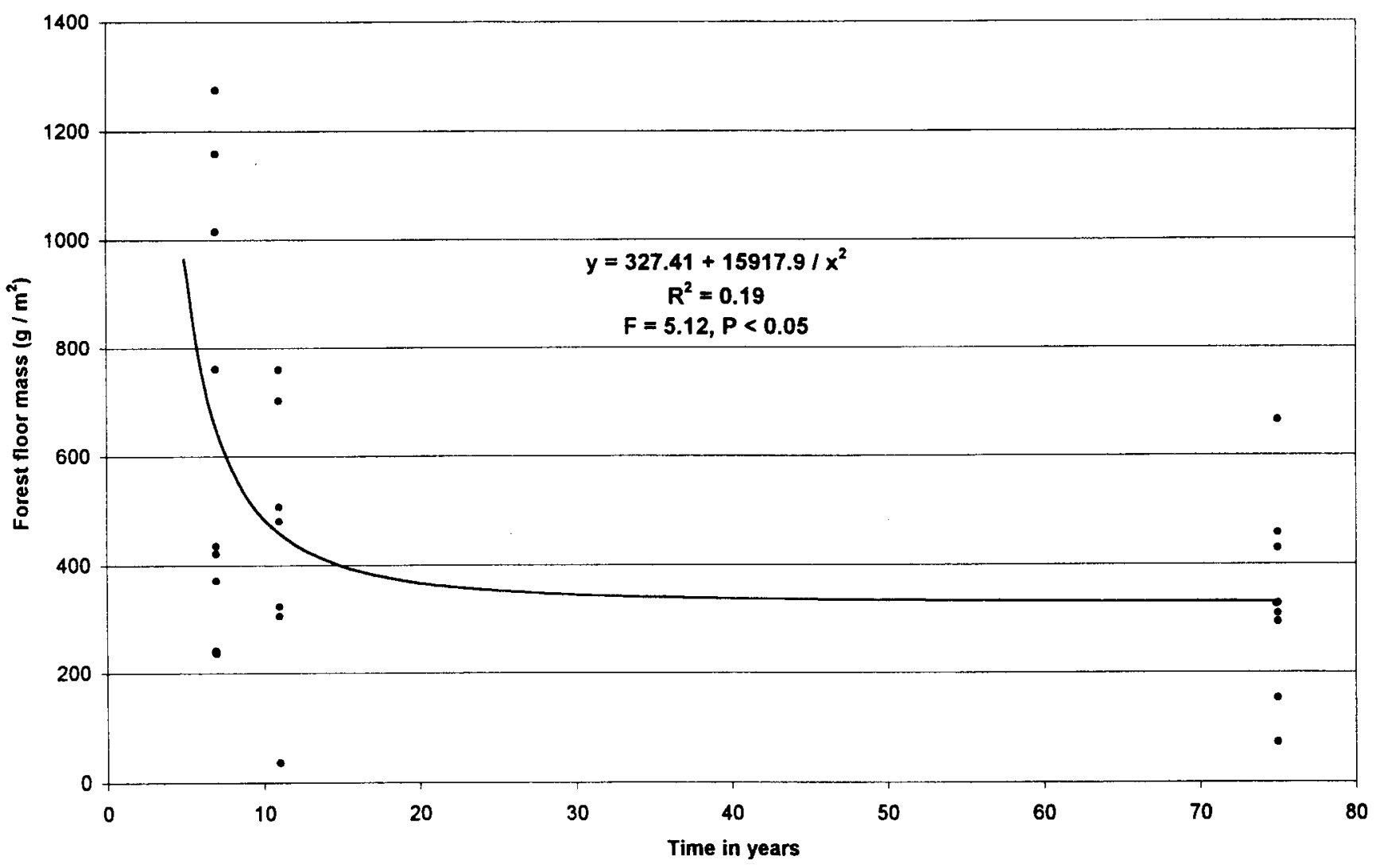

Fig. 3. The relationship between forest floor mass and succession in a forested floodplain chronosequence at the Savannah river site. 
which may enhance forest floor development through increased litter production.

Total forest floor mass at our reference floodplain is about $350 \mathrm{~g} / \mathrm{m}^{2}$. This is considerably less than reports for upland sites, $5600 \mathrm{~g} / \mathrm{m}^{2}$ in northern hardwoods (Covington, 1981); $4680 \mathrm{~g} / \mathrm{m}^{2}$ at Hubbard brook (Gosz et al., 1976); $1400 \mathrm{~g} / \mathrm{m}^{2}$ in Mississippi (Switzer et al., 1979); $1190 \mathrm{~g} / \mathrm{m}^{2}$ in a 55-year pine plantation in North Carolina ( Van Lear et al., 1995); $1150 \mathrm{~g} / \mathrm{m}^{2}$ in warm temperate broadleaf deciduous (Vogt et al., 1986). However, our estimates compare well with Brown (1990), who reported $491 \mathrm{~g} / \mathrm{m}^{2}$ as a mean for litter standing crop in forested basin wetlands of the US. Carbon accumulation in the forest floor paralleled changes in total mass in southeastern uplands (Switzer et al., 1979), and this was observed in our study (Table 1).

The herbaceous fraction of the forest floor greatly decreases through successional time, while the amount of foliage contributed to the forest floor by woody species increases. Herbicide was applied at Pen branch B in September 1993 to control black willow populations, and probably contributed to the unusually low value for percent woody foliage at this site (Fig. 1). In addition, the burning of this site in November 1993 resulted in heavy growth increases of herbaceous/shrubby material. This contributed to the increased level of herbaceous material on the forest floor at Pen branch B (Fig. 1).

The differences among sites that we found in forest floor mass and composition had no effect on the degree of conversion of plant litter to soil organic matter among stages of floodplain succession using the LCI (Melillo et al., 1989). The very low estimates of LCI $(0.31-0.34)$ indicate that the forest floor in each seral stage is dynamic, with a cellulose-lignin relationship that is favorable for rapid degradation. Soil $\mathrm{C}$ appears to be aggrading in this chronosequence, suggesting that the effect by forest floor is a function of differences in mass only, and not LCI relationships. The hydrologic dynamics of floodplains, in conjunction with the warm climates of the southeastern USA may prevent the application of this procedure to studies of succession in floodplain forests. Lockaby et al. (1996) also found evidence to suggest that ligno- cellulose dynamics in flooded, warm temperature sites may differ from upland sites with cooler temperature regimes, in which LCI relationships were developed.

\subsection{Mineral soil}

\subsubsection{Carbon content}

Soil $\mathrm{C}$ content is aggrading in this floodplain chronosequence (Table 4). However, estimates from the regression model (Fig. 2), suggest it will require 25 years from the end of the disturbance event, for the $\mathrm{C}$ content at the experimental sites to reach $50 \%$ of the level at Meyers branch. It will require about 50 years to attain $75 \%$ recovery of the Meyers branch standard. These estimated recovery times demonstrate the sensitivity of floodplain soils, as measured by $\mathrm{C}$ content, to the type of degradation that occurred at SRS.

The estimate for recovery of soil $\mathrm{C}$ is dependent on the age assigned to Meyers branch. We believe that the damage to the soil from logging at Meyers branch some $\sim 75$ years (W.H. Conner. pers. commun.) before sampling was not as severe as the disturbance at Pen branch and Fourmile creek, and therefore the calculated recovery times from regression analyses may be underestimated. The recovery times could be much longer, depending on how depleted soil $\mathrm{C}$ became after the logging. Obviously, it is not possible to know the extent of soil $\mathrm{C}$ loss at Meyers branch during its disturbance. The age assigned to Meyers branch for the purpose of regression analysis, is a known. defensible time of disturbance and something beyond that is merely conjectural. However, assuming $\mathrm{C}$ content at Meyers branch has reached a relative equilibrium, the regression shows the potential successional trajectory of $\mathrm{C}$ content at the disturbed sites. It is very important to make a prediction based on the available data, as one of the primary monitoring and research objectives of the Pen branch restoration is to demonstrate the degree to which the system is on the theoretical, successional trajectory of a recovering forested wetland. The regression analysis was used to construct a successional trajectory of $\mathrm{C}$ accrual, and it is a hypothesis that is subject to further testing that would lead to support or falsification. The 
Steel creek floodplain on the SRS could serve well in this function in that it was also subjected to disturbance similar to Pen branch but has been under natural succession for about 30 years. Steel creek, therefore, would be an invaluable study site for comparing the levels of SOM accrual with that found at Pen branch and Fourmile creek. The most significant information to be gained from our results is that the soil system was very sensitive to the disturbance, and it may require many decades, possibly much longer, for a new equilibrium to be established and for historical biogeochemical functioning to be restored.

Jastrow (1996), in her study of C aggradation in a restored tallgrass prairie chronosequence, predicted that whole-soil organic $\mathrm{C}$ would not reach equilibrium until about 384 years. Brown and Lugo (1990) studied succession from forest clearing in wet, moist, and dry life zones of Puerto Rico and St. John, and found that the recovery time was about the same in all three zones, 40-50 years for $\mathrm{C}$. Our estimates for recovery are about twice that predicted by Brown and Lugo (1990), and may be due to more extensive disturbance of the soil system.

In the study by Brown and Lugo (1990), C content to a $0.5-\mathrm{m}$ depth in the wet life zone ranged from $5-16.5 \mathrm{~kg} / \mathrm{m}^{2}$. Carbon content to a $0.7-\mathrm{m}$ depth in the present study ranged from 15.6 $\mathrm{kg} / \mathrm{m}^{2}$ in the earliest seral stage to $55.9 \mathrm{~kg} / \mathrm{m}^{2}$ in late succession. Our values for $\mathrm{C}$ content are also much higher than that for some upland forests. $3.7 \mathrm{~kg} / \mathrm{m}^{2}$ per $1.0 \mathrm{~m}$ in a 55 -year-old loblolly pine plantation in North Carolina (Van Lear et al., 1995); $7.5 \mathrm{~kg} / \mathrm{m}^{2}$ per $0.45 \mathrm{~m}$ for a $\sim 120$-year-old mixed oak forest in Tennessee (Johnson and Todd, 1997); $13 \mathrm{~kg} / \mathrm{m}^{2}$ (surface-C horizon) for a northern hardwood forest prior to clear-cutting (Johnson et al., 1995); and Missouri uplands which ranged from 8.1 to $13.3 \mathrm{~kg} / \mathrm{m}^{2}$ per $1.0 \mathrm{~m}$ (Hammer et al., 1995). Reviews by Vogt et al. (1995), Lal et al. (1997) estimated $19.8 \mathrm{~kg} / \mathrm{m}^{2}$ per $1.0 \mathrm{~m}$ soil organic matter for global temperate forests, and $13.3 \mathrm{~kg} \mathrm{C} / \mathrm{m}^{2}$ (depth not reported) for temperate deciduous forests, respectively. In Missouri bottomlands, $\mathrm{C}$ estimates ranged from 7.8 to $17.4 \mathrm{~kg} / \mathrm{m}^{2}$ per $1.0 \mathrm{~m}$ (Hammer et al., 1995). Our estimates are more similar to the $5-130 \mathrm{~kg} \mathrm{C} / \mathrm{m}^{2}$ reported by Trettin et al. (1995) for northern forested wetlands.

\subsubsection{Aggregate distribution}

Microaggregates may be bound into macroaggregates by microbial mucilage and this process may be promoted by roots and fungal hyphae (Cambardella and Elliott, 1994; Jastrow, 1996). Jastrow (1996) found evidence to support the hypothesis that the formation of macroaggregates facilitates the accumulation of soil $C$. It is likely that the smaller percentage of macroaggregates $(>2000 \mu \mathrm{m})$ in the disturbed sites, as compared to the standard of Meyers branch, is a result of the breakdown in general soil structure from extensive periods $(30-35$ years) of hydrothermal impact. This breakdown in macroaggregate particles is reflected in a microaggregate $(53-250 \mu \mathrm{m})$ percentage at Pen branch $\mathrm{A}$ and $\mathrm{B}$ that is twice that of the reference standard. However, this is not the case at Fourmile creek where natural succession is 4 years more advanced than Pen branch. At Fourmile creek, there is a very large proportion of small macroaggregates $(250-2000$ $\mu \mathrm{m})$, the size class between microaggregates and macroaggregates, yet the percentage of microaggregates is similar to the reference standard.

This evidence suggests that the slightly longer recovery period at Fourmile creek may have allowed enough time for microaggregates to combine into small macroaggregates, but there has been insufficient time for macroaggregates to form. This discrepancy at Fourmile creek simply may be due to a slightly different soil type in our sampling area as compared to the other sites, but it is not likely. Jastrow (1996) found that macroaggregates $>212 \mu \mathrm{m}$ reached $99 \%$ of equilibrium in 10.5 years. Our data for small macroaggregates $(53-250 \mu \mathrm{m})$ are similar to her findings, but there is no evidence to suggest that the proportion of macroaggregates is increasing in this floodplain chronosequence (see Tables 5 and 6).

\subsubsection{Carbon content in aggregate size classes}

In each size fraction there is a general increase in $\mathrm{C}$ content with succession (Table 7), similar to that described for bulk soil measurements. However, in the macroaggregate fraction, there is a 
Table 9

The ratio of total soil $C$ to the percentage of aggregates in particle size fractions of floodplain soils at the Savannah river site

\begin{tabular}{lllll} 
Site & $\begin{array}{l}\text { Silt-clay } \\
(<53 \mu \mathrm{m})\end{array}$ & $\begin{array}{l}\text { Microaggregates } \\
(53-250 \mu \mathrm{m})\end{array}$ & $\begin{array}{l}\text { Small macroaggregates } \\
(250-2000 \mu \mathrm{m})\end{array}$ & $\begin{array}{l}\text { Macroaggregates } \\
(>2000 \mu \mathrm{m})\end{array}$ \\
\hline $\begin{array}{llll}\text { Pen branch A } \\
\text { Pen branch B }\end{array}$ & $0.24 \mathrm{a}$ & $0.12 \mathrm{a}$ & $0.17 \mathrm{a}$ & $0.28 \mathrm{a}$ \\
Fourmile creek & $0.37 \mathrm{ab}$ & $0.13 \mathrm{a}$ & $0.33 \mathrm{ab}$ & $0.40 \mathrm{ab}$ \\
Meyers branch & $0.54 \mathrm{c}$ & $0.21 \mathrm{ab}$ & $0.30 \mathrm{ab}$ & $0.39 \mathrm{ab}$ \\
$0.60 \mathrm{~b}$
\end{tabular}

a $N=3$ for each fraction at each site: means in a column followed by the same letter are not significantly different at $P>0.10$. according to Duncan's multiple range test.

much greater difference in $\mathrm{C}$ content (Table 7) between the earlier succession sites and Meyers branch, as compared to differences among stages in the smaller fractions. The difference indicates that $\mathrm{C}$ is accruing more slowly over time in the macroaggregate fraction than in other fractions. When $\mathrm{C}$ accrual is examined by the ratio of soil $\mathrm{C}$ content to the percentage of aggregates in particle size fractions, it indicates that $\mathrm{C}$ is accruing more slowly in macroaggregates and small macroaggregates (Table 9). Carbon seems to be accruing preferentially in the silt-clay and microaggregate fraction, as the difference in the ratios between Fourmile creek and Meyers branch is smallest in these fractions, and demonstrates a steady increase over succession. This is not demonstrated in the two larger aggregate size classes. Thus, it appears that small macroaggregates and/or macroaggregates may harbor an enriched labile fraction (Cambardella and Elliott, 1994) that is less resilient to disturbance. Further evidence is produced, therefore, of the extensive period of time that may be required in the accumulation of $\mathrm{C}$, and a correlative development of soil structure, in floodplain soils subjected to severe disturbance.

\section{Conclusions}

Changes in $\mathrm{C}$ pools of the forest floor are primarily driven by changing levels of forest floor biomass in the various stages of succession, rather than element concentrations. The differences among sites that we found in forest floor mass and composition had no effect on the degree of conversion of plant litter to soil organic matter among stages of floodplain succession.

The disturbed floodplain soils at the Savannah River National Environmental Research Park appear to be deficient in $\mathrm{C}$ as well as soil structural qualities when compared to a reference site, and it likely will require many decades for recovery of these characteristics. It will be interesting to observe the long-term effects on soil $C$ of the attempts at enhancing ecological succession at Pen branch B, in comparison with that of Pen branch A and Fourmile creek, where natural succession is occurring. To monitor the long-term trajectory of restoration efforts, it may be sufficient to analyze soil organic matter content, in conjunction with the four aggregate size class distributions. It appears that the distribution of aggregate size classes may change relatively rapidly, although there is no indication that the macroaggregate structure has increased following 11 years of succession. Fourmile creek currently has a much larger proportion of small macroaggregates than the Pen branch sites, indicating that the extra 4 years recovery time may have been sufficient to produce this difference. The Pen branch sites have a disproportionate percentage of microaggregates, and this fraction may decrease over the next few years as microaggregates are bound together into small macroaggregates by biogenic processes (Cambardella and Elliott, 1994: Jastrow 1996). Changes over time in aggregate distribution and whole soil $\mathrm{C}$ accumulation will be important to assessing restoration success. 


\section{Acknowledgements}

This work is supported by the US Forest Service Center for Forested Wetlands Research, Charleston, SC, and the Auburn University School of Forestry, Auburn, AL.

\section{References}

Aber, J.D., Botkin, D.B., Melillo, J.M., 1978. Predicting the effects of different harvesting regimes on forest floor dynamics in northern hardwoods. Can. J. For. Res. 8, 306315 .

Beck, R.E. 1994. The movement in the United States to restoration and creation of wetlands. Nat. Resour. J. 34, $781-822$.

Brown, S., 1990. Structure and dynamics of basin forested wetlands in North America. In: Lugo, A.E., Brinson, M., Brown, S. (Eds.), Ecosystems of the World 15: Forested Wetlands. Elsevier, New York, pp. 171-199.

Brown, S., Lugo, A.E., 1990. Effects of forest clearing and succession on the carbon and nitrogen content of soils in Puerto Rico and US Virgin Islands. Plant Soil 124, 53-64.

Cambardella, C.A., Elliott, E.T., 1992. Particulate soil organic-matter changes across a grassland cultivation sequence. Soil Sci. Soc. Am. J. 56, 777-783.

Cambardella, C.A., Elliott, E.T., 1993a. Carbon and nitrogen distribution in aggregates from cultivated and native grassland soils. Soil Sci. Soc. Am. J. 57, 1071-1076.

Cambardella, C.A., Elliott, E.T., 1993b. Methods for physical separation and characterization of soil organic matter fractions. Geoderma 56, 449-457.

Cambardella, C.A., Elliott, E.T., 1994. Carbon and nitrogen dynamics of soil organic matter fractions from cultivated grassland soils. Soil Sci. Soc. Am. J. 58, 123-130.

Christensen, B.T., 1992. Physical fractionation of soil organic matter in primary particle size and density separates. Adv. Soil Sci. 20, 1-90.

Clements, F.E., 1916. Plant succession: an analysis of the development of vegetation. Publication 242, Carnegie Institute of Washington, Washington, DC, $512 \mathrm{pp}$.

Covington, W.W., 1981. Changes in forest floor organic matter and nutrient content following clear cutting in northern hardwoods. Ecology 62, 41-48.

Dulohery, N.J., Bunton, C.S., Trettin, C.C., McKee, W.H., 1995. Reforestation, monitoring, and research at Pen branch: restoring a thermally-impacted wetland forest. Center for Forested Wetlands Research, Southern Research Station, USDA Forest Service, Charleston, SC.

Ellert, B.H., Gregorich, E.G., 1995. Management-induced changes in the actively cycling fractions of soil organic matter. In: McFee, W.W., Kelly, J.M. (Eds.), Carbon Forms and Functions in Forest Soils. Soil Science Society of America, Madison, WI, pp. 119-138.
Elliott, E.T., 1986. Aggregate structure and carbon, nitrogen, and phosphorus in native and cultivated soils. Soil Sci Soc. Am. J. 50, 627-633.

Elliott, E.T., Cambardella, C.A., 1991. Physical separation of soil organic matter. Agric. Ecosyst. Environ. 34, 407-419.

Gosz, J.R., Likens, G.E., Bormann, F.H., 1976. Organic matter and nutrient dynamics of the forest and forest floor in the Hubbard brook forest. Oecologia 22, 305-320.

Hammer, R.D., Henderson, G.S., Udawatta, R., Brandt, D.K., 1995. Soil organic carbon in the Missouri forestprairie ecotone. In: McFee, W.W., Kelly, J.M. (Eds.), Carbon Forms and Functions in Forest Soils. Soil Science Society of America, Madison, WI, pp. 201-231.

Hauer, F.R., 1989. Organic matter transport and retention in a blackwater stream recovering from flow augmentation and thermal discharge. Regul. Rivers: Res. Manage. 4, $371-380$.

Henderson, G.S., 1995. Soil organic matter: a link between forest management and productivity. In: McFee, W.W., Kelly, J.M. (Eds.), Carbon Forms and Functions in Forest Soils. Soil Science Society of America, Madison, WI, pp. 419-435.

Hodges, J.D., 1997. Development and ecology of bottomland hardwood sites. Forest Ecol. Manage. 90, 117-125.

Jastrow, J.D., 1996. Soil aggregate formation and the accrual of particulate and mineral-associated organic matter. Soil Biol. Biochem. 28, 665-676.

Johnson, C.E., Driscoll, C.T., Fahey, T.J., Siccama, T.G., Hughes, J.W., 1995. Carbon dynamics following clear-cutting of a northern hardwood forest. In: McFee, W.W., Kelly, J.W. (Eds.), Carbon Forms and Functions in Forest Soils. Soil Science Society of America, Madison, WI, pp. $463 \sim 488$

Johnson, D.W.. Todd, D.E. Jr, 1997. Effects of harvesting intensity on forest productivity and soil carbon storage in a mixed oak forest. In: Lal, R., Kimble, J.M., Follett, R.F., Stewart, B.A. (Eds.), Management of Carbon Sequestration in Soil. Advances in Soil Science Series. CRC Press, Boca Raton, FL, pp. 351-363.

Johnson, J.E., Smith, D.W., Burger, J.A., 1985. Effects on the forest floor of whole-tree harvesting in an Appalachian oak forest. Am. Midl. Nat. 114, 51-61.

Kanazawa, S, Filip, Z., 1986. Distribution of microorganisms, total biomass, and enzyme activities in different particles of brown soil. Microb. Ecol. 12, 205-215.

Kentula, M.E., Brooks, R.P., Gwin, S.E., Holland, C.C., Sherman, A.D., Sifneos, J.C., 1992. An approach to improving decision making in wetland restoration and creation. In: Hairston, A.J. (Ed.), US Environmental Protection Agency, Environmental Research Laboratory, Corvallis, OR, $151 \mathrm{pp}$.

Killham, K., 1994. Soil Ecology. Cambridge University Press, New York, $242 \mathrm{pp}$.

Kolka, R.K., Singer, J.H., Coppock, C.R., Casey, W.P., Trettin, C.C., 2000. Influenced restoration and succession on bottomland hardwood hydrology. Ecol. Eng. (this issue). 
Lal. R.. Kimble. J.. Folett. R.. 1997. Land use and soil C pool in terrestrial ecosystems. In: Lal, R., Kimble, J.M.. Follett. R.F., Stewart, B.A. (Eds.), Management of Carbon Sequestration in Soil. Advances in Soil Science Series. CRC Press, Boca Raton, FL, pp. 1-10.

Lockaby, B.G., Wheat. R.S., Clawson, R.G., 1996. The influence of hydroperiod on litter conversion to soil organic matter in a floodplain forest. Soil Sci. Soc. Am. J. 60. $1989-1993$

Marks, P.L., Bormann. F.H., 1972. Revegetation following forest cutting: mechanisms for return to steady-state nutrient cycling. Science 176, 914-915.

Mattson, K.G., Smith, H.C., 1993. Detrital organic matter and soil $\mathrm{CO}_{2}$ efflux in forests regenerating from cutting in West Virginia. Soil Biol. Biochem. 25, $1241 \cdots 1248$

McColl, J.G., Gressel, N., 1995. Forest soil organic matter: characterization and modern methods of analysis. In: McFee, W.W., Kelly, J.M. (Eds.), Carbon Forms and Functions in Forest Soils. Soil Science Society of America. Madison, WI, pp. 13-32

Melillo, J.M., Aber, J.D., Linkins, A.E., Ricca, A., Fry, B. Nadelhoffer, K.J., 1989. Carbon and nitrogen dynamics along the decay continuum: plant litter to soil organic matter. Plant Soil 115, 189-198

Mitsch, W.J., Cronk, J.K., 1992. Creation and restoration of wetlands: some design considerations for ecological engineering. Adv. Soil Sci. 17. 217-259.

Oades. J.M., 1989. An introduction to organic matter in mineral soils. In: Minerals in Soil Environments, second ed.. SSSA Book Series, No. 1. Soil Science Society of America, Madison, WI, pp. 89-159.

Odum. E.P., 1960. Organic production and turnover in old field succession. Ecology 41, 34-49.

Pritchett. W.L., Fisher, R.F., 1987. Properties and Management of Forest Soils. Wiley. New York. 494 pp.

Rogers. V.A., 1990. Soil survey of Savannah river plant area. parts of Aiken, Barnwell, and Allendale counties, South Carolina. United States Department of Agriculture, Soil Conservation Service.

Sharitz, R.R., Mitsch, W.J.. 1993. Southern floodplain forests. In: Martin. W.H., Boyce. S.G.. Esternacht, A.C. (Eds.). Biodiversity of the Southeastern United States: Lowland Terrestrial Communities. Wiley, New York, pp. 311--372.

Stevenson, F.J., 1994. Humus Chemistry: Genesis. Composition, Reactions. Wiley, New York, 496 pp.

Swift, M.J., Heal, O.W., Anderson, J.M.. 1979. Decomposition in Terrestrial Ecosystems. Studies in Ecology, vol. 5. University of California Press, Berkeley. $372 \mathrm{pp}$.
Switzer, G.L.. Shelton. M.G., Nelson, L.E.. 1979. Successional development of the forest floor and soil surface on upland sites of the East Gulf Coastal Plain. Ecology 60, 11621171.

Theng, B.K.G.. Tate, K.R., 1989. Interactions of clays with soil organic constituents. Clay Res. $8(1-2), 1-10$.

Trettin. C.C.. Jurgensen, M.F.. Gale, M.R.. McLaughin. J.W. 1995. Soil carbon in northern forested wetlands: impacts of silvicultural activities. In: McFee, W.W., Kelly. J.M. (Eds.), Carbon Forms and Functions in Forest Soils Soil Science Society of America, Madison, WI, pp. 437 461.

Van Cleve, K., Viereck, L.A., 1981. Forest succession in relation to nutrient cycling in boreal systems of Alaska. In: West, D.C., Shugart, H.H., Botkin, D.B. (Eds.), Forest Succession: Concepts and Application. Springer, New York, pp. 185-211.

Van Lear, D.H., Kapeluck, P.R., Parker, M.M., 1995. Distribution of carbon in a piedmont soil as affected by loblolly pine management. In: McFee, W.W., Kelly, J.M. (Eds.), Carbon Forms and Functions in Forest Soils. Soil Science Society of America, Madison, WI, pp. 489-501.

Van Soest. P.J.. Wine, R.H., 1968. Deter ination of lignin and cellulose in acid-detergent fiber with permanganate. $J$. Assoc. Official Anal. Chem. 51, 780 .785.

Vogt, K.A., Grier, C.C., Vogt, D.J., 1986. Production. turnover. and nutrient dynamics of above- and belowground detritus of world forests. Adv. Ecol. Res. 15. 30) $3-377$.

Vogt, K.A., Vogt, D.J., Brown, S.. Tilley, J.P., Edmonds. R.L., Silver, W.L., Siccama, T.G., 1995. Dynamics of forest floor and soil organic matter accumulation in boreal, temperate, and tropical forests. In: Lal, R., Kimble, J.. Levine. E.. Stewart, B.A. (Eds.), Soil Management and Greenhouse Effect. Advances in Soil Science Series. CRC Press, Boca Raton. FL, pp. 159-178.

Walbridge. M.R.. Lockaby, B.G.. 1994. Effects of forest management on biogeochemical functions in southern forested wetlands. Wetlands 14, 10-17.

Williams. E.P.B., Mice, P.E., 1994. From reclamation to restoration-changing perspectives in wetland management In: Falconer, R.A.. Goodwin, P. (Eds.), Wetland Management. Proceedings of the International Conference. American Society of Civil Engineers. New York, NY, pp. I-6.

Witkamp. M.. 1971. Soils as components of ecosystems. Annu. Rev. Ecol. Syst. 2, 85-110. 